Article

\title{
Shapeshifting the Scottish Borders: A Geopoetic Dance of Place
}

\author{
Claire Pençak \\ Northumbria Law School, Northumbria University, Newcastle upon Tyne NE1 8ST, UK; \\ claire.pencak@northumbria.ac.uk
}

Received: 30 June 2019; Accepted: 1 August 2019; Published: 7 August 2019

\begin{abstract}
In this paper, I unite dance theory and practice and geopoetics in order to reflect on edges, peripheries and borders in a geographic region, the Scottish Borders, where the dominant cultural narrative is and has historically been based on rivalry. I draw here on the writing of the Scottish poet-philosopher Kenneth White, the practices of specific dancers and choreographers and on relational accounts of place and more-than-human perspectives. Rather than 'sense of place', my interest is in sensing place and thinking through sites. Threaded throughout are descriptions of perception practices exploring woodland, stone and riverways, which take the reader into the more experiential realm of embodied knowing. These passages are an invitation to be present with more-than-human others, to be in contact with the vitality of materials and to allow for being shaped, rather than being the shaping force. The intention is to bring different bodies of knowledge into contact as a way of revealing other vocabularies within place, which suggest alternative cultural narratives and help create the conditions for place-making a more collaborative, ethical and less anthropocentric endeavour, open to the influence and organising principles of the more-than-human.
\end{abstract}

Keywords: dance; more-than-human; place; geopoetics; perception

\section{Introduction}

This foray into the Scottish Borders draws on the dwelling perspectives of being both an inhabitant and a dancer working in improvisation and somatic movement techniques with a collaborative, place-based choreographic practice. It is a project in the spirit of the Scottish biologist and town planner Patrick Geddes (1854-1932), who embraced 'vivendo discimisus', by living we learn, and 'creando pensamus', by creating we think or, more specifically, by dancing we think.

The Scottish Borders is historically an edgy place of debatable lands and is the only Local Government region in Scotland which takes its name, not from geography but from a political and cultural construct-a national border'(Openshaw 2014, p. 9). The Scottish Borders Cultural Strategy notes that 'The Border and the idea of 'borders', of boundaries and distinct, often competing, communities, are central to the identity of the region' (ibid.). This prevailing cultural narrative is repeatedly played out in reiving, rugby and common riding traditions and dominates the story that the Scottish Borders tells visitors and itself. I follow the poet Kenneth White's geopoetic spatial positioning when he writes:

I must enter this birch- world

And speak from within it

From 'Valley of Birches' (White 2003b, p. 275)

This is an invitation to go further into the territory and, from being 'in the midst', to make deeper contact with more-than-human perspectives. I will explore this invitation by thinking through 
geological (stone ways), biological (woodland ways) and hydrological (riverways) sites; through movement practice and theory; and through conversations with Ronnie Glass, a Kelso fisherman and Scottish National Trout Fly Fishing Champion, and Jedburgh-based artist and deer manager Tom Hawson. ${ }^{1}$ The writings from practice, indicated in italics in this essay, are written in a different voice that is more expressive of how I speak from within my practice, in a workshop or studio context. These sections are intended to foreground the kinaesthetic practice for the reader and are an invitation to become 'present with' the activities being described. I will draw on artistic collaborations and activities that I have been involved with in the Scottish Borders between 2013 and 2019. This includes movement workshops with the Extending Practice Group (2014-present), an informal gathering of Scottish Borders artists from different art forms who meet once a month to move and make together; an ongoing artistic dialogue with visual artist Felicity Bristow (2017-present) ${ }^{2}$; and an art-science collaboration, Working the Tweed (2013-2014). ${ }^{3}$ Edges and margins as river banks featured in a previous collaboration with dancers Tim Rubidge and Merav Israel and visual artist Kate Foster and were presented as a paper work, 'Approaching Choreography'. ${ }^{4}$ I make reference to the work of generations of dancers from different continents, including Anna Halprin (United States of America (USA)), Dominique Dupuy (France), Lisa Nelson (USA), Mary Overlie (USA), Russell Dumas (Australia) and Rosanna Irvine (Scotland). These are mentioned because I have brushed up against their dance practices to varying degrees over the years, either directly or through their legacy in another dancer-knowledge in dance passing from body to body. I also move with Erin Manning's choreographic thinking, which extends from Alfred North Whitehead's process philosophy and Gilbert Simondon's theory of individuation, as well as with 'choreographic dwelling' as 'an intricate manifold of sensation, action and environment', as proposed in 'Choreographic Dwellings. Practising Place' (Schiller and Rubidge 2014, p. 2). My main concern here, however, is with the spatial constructs of edges, peripheries and borders by bringing dance into contact with other bodies of knowledges, in particular, the transdisciplinary geopoetic 'work-field' of Kenneth White (2003a, p. 17). I am concerned with geography in that this project moves through the Scottish Borders, and I invoke Doreen Massey's discussion of constructions of place as distinct meshes of networks open to the wider world (Massey et al. 2009). I also draw on philosopher Val Plumwood (Plumwood 2008) and ethnographer Deborah Bird Rose (2017), whose complex, shifting and relational accounts of place are 'thicker and more concrete than mere location' (Plumwood 2008, p. 144). Each of these perspectives challenges the notion of place as bounded, fixed and singular and offers a counternarrative to bring to the Scottish Borders region. ${ }^{5}$ Leah Gibbs' 'passing through place' (Gibbs 2014) foregrounds moving-through as an organising principle, which segues into Erin Manning's expanded choreographic thinking, where 'movement is not of a body. It cuts across, co-composing with different velocities of movement-moving. It bodies.' (Manning 2013, p. 14). These approaches make way for a less anthropocentric stance and for co-creative relationships where we allow more-than-human others to influence placemaking processes. The following is best described as a meander through practises of place in a search for new vocabularies to suggest different ethical constructions and provide propositions for participatory placemaking within the Scottish planning processes.

\footnotetext{
Dr. Thomas Hawson is a designer, maker and artist at Hundalee, near Jedburgh: www.thomashawson.com. Felicity Bristow is a visual artist living and working in the Scottish Borders: http://www.felicitybristow.com/. Working the Tweed was a Year of Natural Scotland 2013 collaboration between artists and environmental organisations: https://workingthetweed.co.uk/.

4 Web version here https://clairepencak.files.wordpress.com/2016/11/approaching-choreography-web-version.pdf.

5 I would like to acknowledge that moving through the Scottish Borders has also been an artistic enquiry for other artists, such as Zoe Childerley and Alec Finlay, both of whom exhibited in the Mapping the Borders exhibition as part of the Being Human Festival in November 2017. Walking is the activity that has informed their still images and texts and is a choreographic form in itself. My interest here is specifically in somatic practice and in the compositional processes of movement as a way of enquiring, and the work lies and remains mainly within the body-mind rather than through another media.
} 


\section{Woodland Ways: Opening into Place}

The first inhabitants were lichens, mosses, bog cottons, birch, holly, pine, hazel, oak ... And the bear, the deer, the wolf, the red deer, the eagle, the grouse, the snow bunting. (White 1984, p. 9)

We have come into the Haining woods. Find someone else to work with. One of you will close your eyes and explore the woodland unsighted in your own way. Give yourself time to notice what information becomes available to you-what takes your interest. How does being unsighted compose your moving differently? What new elements of the woodland reveal themselves to you? Your partner is there to accompany and assist you in navigating the woodland in safety. They can act as a guide where it is necessary but are not leading or directing the exploration. Guiding might be by lightly taking the elbow and forearm of the unsighted mover, which allows for some gentle steering, and/or by giving verbal directions to help navigate obstacles and changes of ground. Allow the mover to drop into a slower pace. Does the experience of accompanying an unsighted mover change your moving? What is revealed to you? Give yourself at least 15 minutes for this exploration, and then, find a place to pause. Describe to your partner where you think you are, and then, open your eyes. Change roles and share your experiences at the end. There is nothing new about this exercise, and I have done it many times in different situations, but it is always absorbing. In the vocabulary of dancemaker, improvisor and videographer Lisa Nelson, it is a 'tuning' activity. Working unsighted, especially when at all familiar with a place, reveals it to us afresh and in different ways. Each contact-the feet navigating the woodland floor, the hands finding a branch as it extends away out into the space, the movement of air, our sensitivity to light and shade-is an opening into a fresh way of knowing, moment by moment. In our habitual ways of perceiving being disrupted, we become alert and open to every encounter, listening through the fingers - the skin-hearing the voice of your partner close by, the sounds underfoot, the rustle of leaves, birds, perhaps a dog and dog walker passing through. Every contact is a conversation, and the liveliness of the woodland becomes apparent. Time shifts as you are absorbed into the activity. Duration, as a measurement of minutes falls away, and the space-time zone becomes denser. We slow down for the obvious reason of working unsighted, but also because we are filling each moment in gathering invisible data through touch, the air, smell and the kinaesthetic sense. Much time is needed to be in such close contact with the multiple and shifting complexities of place and the presence of more-than-human others.

\section{Peripheral Visions}

the whole I'm out for

is centre plus circumference

From 'Walking the Coast' (White 2003b, p. 154)

Our habitual visual framework contributes to what Val Plumwood calls our 'hyperseparation' from the biosphere, one of the manifestations of how, particularly in Western culture, we compose ourselves by separating out mind from body, male from female, nature from culture (Rose 2017, p. 493). How we cast our gaze can reinforce the impression that the world exists out and over there, from which we are removed or 'cast out' (Rose 2017). The perception practice described above was the first part of an Extending Practice session that took place on 27 November 2018. Working unsighted moves us from the mundane and rehearsed to experience place through other senses that sight can overshadow-in particular touch, sound and the kinaesthetic sense. This was the beginning of a collaboration with artist and roe deer manager Tom Hawson, which evolved over a series of monthly sessions from October 2018 to April 2019 and took place in the woodland on two Scottish Borders estates-the Haining and Bowhill—as well as in the Studio on the Green, Selkirk (Figures 1-3). The group came to appreciate the dwelling practices of roe deer by grounding their movement explorations in how they perceive and attune themselves using scents and sounds, paying attention to up and down wind positionings and taking cues from other woodland dwellers, such as birds. One of these perception practices was the 
exploration of the visual perspective used by deer, enabled by the positioning of their eyes, which allows them to keep the edges where predators might lurk in view.

Stretch both your arms out to either side, level with your shoulders. Now wriggle the fingers of both hands. You should be able to register this movement in the corner of your eyes. This is peripheral vision, a widening of the gaze to take in what is happening at the edges and used by performers to increase their spatial awareness. Explore the woodland now, using only peripheral vision, maintaining an awareness of where others are.

Sustaining this kind of gaze calls for a different action of the eye, which requires practice and is difficult to maintain over a long period. We sense this change as a dropping of the eyes back into the skull and a shift in attention, which encourages a more open gaze and a listening quality in the whole body, making us more alert to what is around, beneath and above. We noticed that whilst peripheral vision makes navigating uneven ground tricky, as you are not able to see what is directly in front of you, it heightens the architecture of the surrounding environment. The verticals of the trees and distant hills are foregrounded, and movement registers clearly. I noticed my usual stepping pattern had changed, and in navigating uneven ground, I was lifting my feet high to avoid tripping over branches. It was a reminder of the capacity of my feet to adapt to different circumstances and to knowingly reorganise appropriately to the conditions underfoot. The stepping had a quality of lightness as I picked my way through the woodland more delicately than I would do normally. The rhythm and the quality of stepping, it seemed to me, could be described as deer-like in appearance and allowed me to edge perhaps a little closer to qualities of deer-ness. Tom Hawson explained that deer managers practice peripheral vision before going into the 'field', as it attunes them to the environment and creates a demeanour that is less predatory and so less likely to trigger alarm. To the same end, he also finds ways to crouch and move through the woodland that create a less recognisably human stance and form. We explored what less human stances might be in the studio, but it came more easily in the woodland habitat.

Space is a major organising principle in dance, which articulates the poetics of space rather than place. The German-American phenomenologist and neurologist Erwin Straus, a contemporary of movement theorist Rudolf Laban, used the term 'wide openness', which 'is neither here nor on the horizon, nor is it on a line connecting the here with any other points of space or such points with each other; it is not quantifiable but is rather a quality of space. Thus, ... dance movement is ordered according to the symbolic qualities of space' (Straus 1966, p. 35). Peripheral vision is one way to approach this state of 'wide openness' and introduces us to the materiality of space-a vibrant material that we can cocreate with rather than something to be filled, shaped and constructed. Mary Overlie, author of the Six Viewpoints performance theory and practice, observes that dancers with undeveloped spatial perception 'unconsciously behave as if they are the centre of attention ... Space is only where they are and centre stage just seems the right place to stand' (Overlie 2016, p. 12). Horizontal and sideways positioning appear in Jane Bennett's political theory, where ' $[\mathrm{m}]$ ateriality is a rubric that tends to horizontalize the relations between humans, biota, and abiota. It draws human attention sideways, away from an ontologically ranked Great Chain of Being and toward a greater appreciation of the complex entanglements of humans and nonhumans' (Bennett 2010, p. 112). This was reflected in a workshop participant's experience of working with peripheral vision at the Geopoetic Conference, where she 'felt to be the centre but extended out. Not necessarily a self in the same way, because extended, relational and I wasn't being perceived as a self by anyone else.' 


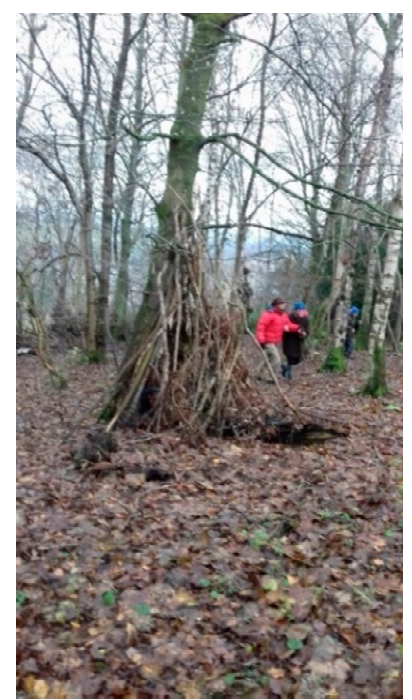

Figure 1. Extending Practice Sessions at the Haining and Bowhill Woods. Image, author's own.

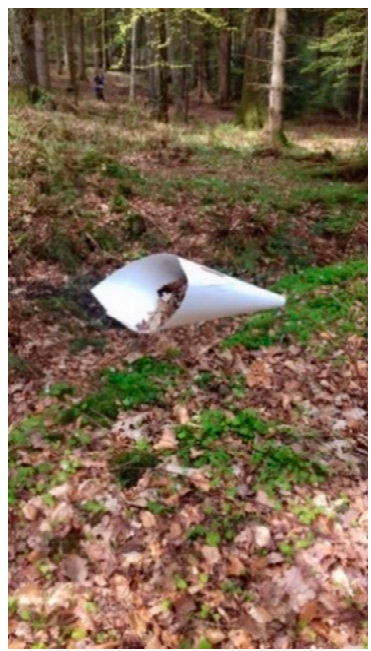

Figure 2. Extending Practice Sessions at the Haining and Bowhill Woods. Image, author's own.

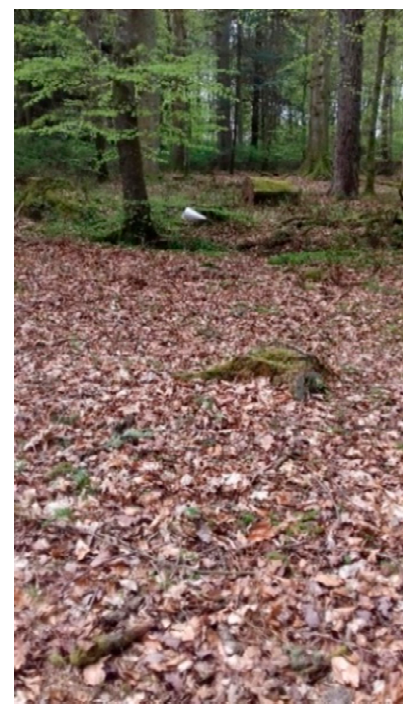

Figure 3. Extending Practice Sessions at the Haining and Bowhill Woods. Image, author's own. 
One rainy day, we reflected on our woodland explorations in the dry of the studio. I brought in a variety of different materials to make and improvise with. What emerged was a collection of sculptural objects made from withies and paper that expressed, in their various forms, an extension and amplification of 'listening'. Large pieces of paper shaped into cones literally resembled old fashioned ear trumpets. Once attached to long withies, they became more labile, a term used by movement theorist Rudolf Von Laban. Representing the opposite of stability, lability allows for flux and is associated with relinquishing control and allowing momentum-movement moving-to be the shaping force. These attuning devices—or might we call them choreographic objects? (Forsythe n.d.) ${ }^{6}$-were an imaginative response to the ways that roe deer gather information through sound, smell and vision about what is taking place in the near and far space around them. Holding a sculptural object in each hand, they could operate independent of each other in the way that the ears of deer do, which enables them to attend to more than one sound coming from different sources in different places. These became the starting point for a woodland session at Bowhill and guided our moving through the sites. The withies have a vitality and motion of their own, and by extending the attention into and through the object, this motion can be channelled through and taken on by the body. It is an act of imagination and requires a lightness of touch, but not so light that contact with the object is lost and we become literally out of touch. In this way, the paper sculptures shaped the quality of our moving through the woods. In our slowness, we became porous to woodland, sensing through willow the suppleness of place, listening in to insects, trees, plants, birds, air waves, drawn on by pathways not of our own making. They acted as 'antennae' and encouraged a greater quality of listening through the whole body. Working through an object can often be an easier way, especially for non-dancers, to find this quality, as it directs attention away from the self and into something else, which diverts any self-consciousness elsewhere.

\section{Sensing Place}

The body is a tuning instrument composed of finely differentiated antennae. These are our senses, and they measure change. (Nelson 2004, p. 3)

Somatic movement and dance practices offer many ways to cultivate sentient knowledge and to become more fully present with space. As well as appraising change, 'sensations to a large degree organize the mind. They do not simply give the mind material to organise; they are themselves a major organising principle' (Juhan 1995, p. 364). Touch and skin, as the sensing organ of touch, is often a focus of these practices, which is grounded in the science of embryology. Embryological development begins from three primitive cell types—-the endoderm, mesoderm and ectoderm-each responsible for the development of different parts of the body. As both the skin and the central nervous system are formed from the ectoderm Juhan invites the reflection that '[d]epending upon how you look at it, the skin is the outer surface of the brain, or the brain is the deepest layer of the skin' (Juhan 1995, p. 364). We are, then, all skin deep. Deanne Juhan, a somatic practitioner, describes the relationship as similar to that between the surface and the bottom of a lake in which the skin and mind is an extended unit from 'cortex to fingertips to toes' (Juhan 1995, p. 364). This is an embodiment of connectivity and integration, and as Rose states, '[c]onnectivity thinking radically challenges hyperseparation' (Rose 2017, p. 494). Choreographer Rosanna Irvine rephrases skin deepness as the 'surface-depth continuum' (Irvine 2016) to express the potential of residing in different degrees of spatiality across the spectrum of surface through to depth. This extends our range of possibilities as dancers and inhabitants and asks us to be aware of where we are at any moment. The French dancer Dominique Dupuy goes further out and describes movement as 'the beyond-skin'7. Continuing this thought line, Erin Manning asks, 'what if the skin were a porous, topological surfacing of myriad potential strata that field the relation between different milieus, each of them a multiplicity of insides and outsides?'

6 A concept developed by choreographer William Forsythe. See online essay https://www.williamforsythe.com/essay.html.

7 Dominique Dupuy. 2010. Workshop Handout. 
(Manning 2013, pp. 1-2). These enquiries offer a provocation to conventional notions of personal edges and borders in relation to our own sense of self, which is not contained by, but is fielded by, skin. The dancer Steve Paxton, in referring to his contact improvisation practice, called The Stand or the Small Dance, notes 'I sense the small dance as a body-field event, centerless. ${ }^{8}$ Might we then extend Manning's 'what if' proposition to geophysical and geopolitical edges and borders and consider a very different dance of place emerging? I imagine a multiplicity of rearrangements and positionings arising as a constantly transforming real-time composition with more-than-human vitalities-a distributed rather than a dividing place.

A major concern of Anna Halprin's dance work is re-establishing our kinship to the rest of the natural world, cultivated in part by her relationship with indigenous cultures (Worth 2004, p. 86). One of the creative activities she works with is 'contact-contour', a process which folds two ways of being in a relationship into one phrase. 'Contact' is a process of 'becoming familiar with the materiality of the element through the physicality of the body and the senses' (Worth 2004, p. 89). As well as being a direct encounter through the sense of touch, contact might also be a quality of gaze-a certain kind of regard, as we have explored above. Contouring is a way of coming to know through shape, edge and surface. My embodied understanding of contact-contour has come from working with choreographer Audicia Lynne Morley, who has studied and worked with Anna and Daria Halprin and is a co-director of Tamalpa UK. ${ }^{9}$ We have been developing a choreographic work, 'Moss: An Appreciation', which requires me to find ways to move that give expression to moss through qualities of porousness and the spreading and the taking of time. In this process, to begin to approach moss, I have needed to relinquish the structure of the human form that so strongly shapes our moving and presence in the world and to allow unfamiliar movement patterns to emerge. Unlearning is a slow trajectory and requires finding other resources or starting points within the body from which to work. We have been drawing inspiration from the writing of Robyn Wall Kimmerer, who, in her description of the dwelling practices of moss, could be writing here about contact-contour. 'Mosses inhabit surfaces ... that small space where earth and atmosphere first make contact ... Lying cheek to cheek with rocks and logs, mosses are intimate with the contours and textures of their substrate'(Kimmerer 2003, p. 15). Here, we are entering into the territory of places of contact, and moss offers a fine example of where 'the most important side of any department of knowledge is the side on which it comes into contact with every other department' (Macdonald 2015). ${ }^{10}$ 'Moss' in the Borders refers to a peat or fenland habitat of which, historically, there were once many. 'Moss Troopers' was the name given to the raiders or reivers that operated along and across the Anglo- Scottish Border. Now, it is these mosses themselves and the wildlife they support that need defending and protecting and are designated sites of special scientific interest. ${ }^{11}$ This is rich research territory, and there is much that could be drawn out here around moss and peatlands that relates to otherness, edges and peripheral spaces, but this warrants, literally and metaphorically, more space than is available here. In the context of this essay, following moss has taken me into working with the body as a landscape rather than a bodyscape-a less anthropocentric shaping of self. Moss also leads into the next section, the geopoetic realm of rocks, which 'are beyond slow, beyond strong, and yet yielding to a soft green breath as powerful as a glacier, the mosses wearing away their surfaces, grain by grain bringing them slowly back to sand' (Kimmerer 2003, p. 5).

8 Note 6 by Steve Paxton made in 2008 in reference to a transcript of a 1977 class working on The Small Dance/The Stand: https:// myriadicity.net/contact-improvisation/contact-improv-as-a-way-of-moving/steve-paxton-s-1977-small-dance-guidance.

9 The Tamalpa Life Art Process as developed by Anna and Daria Halprin is available in the United Kingdom (UK) through the teaching programme of Tamalpa UK: http://www.tamalpa-uk.org/.

10 Macdonald (2015) quoting John Burnet, Professor of Greek at St Andrews University, p. 82.

11 Bemersyde Moss, Gordon Moss, Hare and Dunhog Moss, Hoselaw Loch and Din Moss are all moss reserves currently managed by the Scottish Wildlife Trust. 


\section{A Geopoetic Viewpoint}

these Borders border on more than England

the border between nation and nation

is hardly interesting after all ...

what matters

is the border

between humans and inhuman

between one field of knowledge and another

between spirit and matter...

only

in a mind on the edge

a sense of near-infinite space

and of moving, complex reality

rough wind, a rock and a rowan tree.

From 'On the Border' (White 2003b, pp. 34-37)

This poem starts at Carter Bar-the Anglo-Scottish border point traversed by the A68 (Figure 4), which has set a tone for the borderlands that is inscribed in the cultural practices and narratives that are reiterated within the region itself. Rivalry comes from the sixteenth-century Latin rivoalis-literally, one who shares the same brook, from rivous, a brook (from the root 'to run, flow') or one that dwells on the opposite bank of the stream ${ }^{12}$. This 'stream' is the River Tweed and all the tributaries and groundwaters that flow into it. In one respect, these rivalries create strong communities with a deep sense of belonging within the individual towns, but these fierce allegiances make cooperation between towns and across the region fractious and occasionally impossible. Historically, the edges of settlements were tightly controlled and bounded by traditional practices of riding the marches to protect common lands from encroachment by neighbouring landowners. Although no longer required for this reason, the annual Common Riding festivals continue to reinforce this demarcation of territory in the many ride-outs on horseback that take place throughout the summer. This geopolitical border is of little interest to Kenneth White, and his description is of a more-than-human place composed by 'rough wind, a rock and a rowan tree'. His concern is to give voice to more-than-humankind worldings and wordings, which allows for worldmaking processes where homo sapiens are otherwise situated.

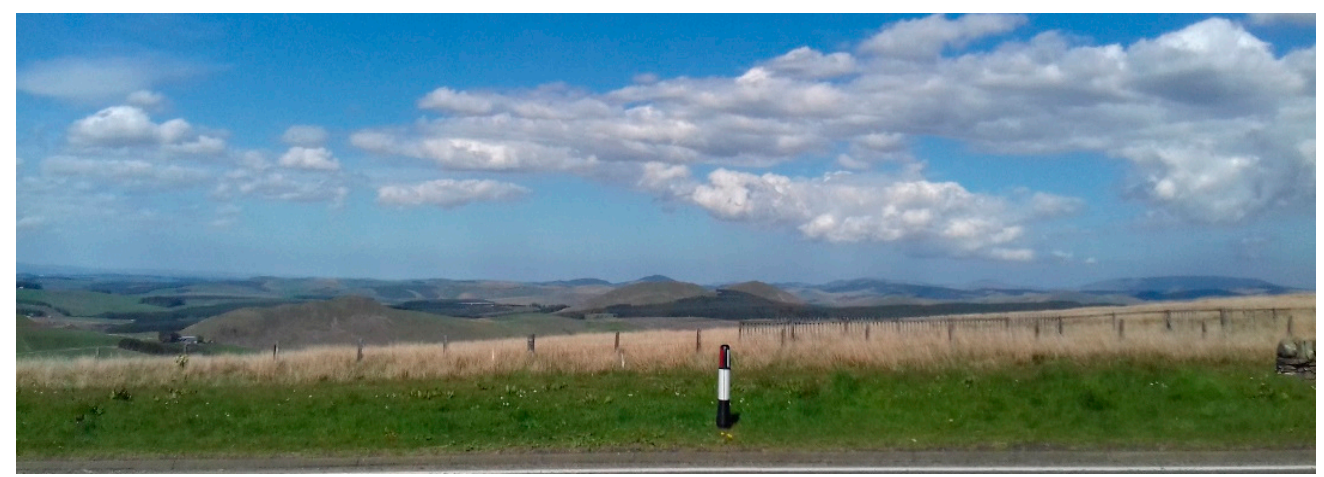

Figure 4. The view looking east across to the Cheviots at Carter Bar, Scotland. Image, author's own.

12 https://www.etymonline.com/word/rival. 


\subsection{Stone Ways: A Geopoetic Practice}

We are going to take a long, slow walk with stone. We can do this in the open air or in a studio space. You need a fair amount of space, and if inside, it is ideal to walk towards a window so you can extend the gaze out beyond the room. In either situation, it is best practised barefoot if the ground allows. Take a stone in each hand. Hold them securely but not tightly, as too much muscular tension closes you off from sensing the heft of the stone. Allow the density of them to fall into your palm, and let the fingers have a looseness to them. Drop your attention into the stones, and let them ground your focus, your breathing. We are going to walk in a way that is more a planting of the feet than stepping. Where we usually transfer the weight through the foot from heel to toe, we are going to place the foot down as a whole. Only lift the foot enough off the floor to be able to move it forward so that the heel is in line with the arch of your other foot. Each step is very small. Feel like you are walking into, rather than on, the ground. Allow the movement of placing the foot into the ground to finish completely. There is no hurry to progress to the next step. Take all the time that it needs and then a bit more. Only then take the other foot just off the ground enough to be able to drop it down level with the arch of the other foot. Look straight ahead and be aware when the gaze goes inward or becomes more similar to a stare. It can be helpful to focus on something in the distance and to keep the eyes light and moving slightly. Continue like this either until you run out of space or have travelled some distance. Do not be tempted to stop too early. Let the patience of stone lead you on a long journey. ${ }^{13}$

\subsection{Beyond Borders}

Where the path ends

the changes begin

and the rocks appear

ideas of the earth.

From 'Stones of the Cloudy Forest' (White 2003b, p. 431)

From Carter Bar, continue along the A68 northwards, and just before arriving into the 'gateway' town of Jedburgh, you pass over the geological site of Hutton's Unconformity, just below Inchbonny beside the Jed Water. 'Here in fact we go back beyond Scotland, into the basics of geomorphology' (White 1984, p. 7). In 1787, the Berwickshire farmer and geologist James Hutton came across this geological formation that was to inspire his 'Theory of the Earth' (1795). The Unconformity is the junction of two different earth-building eras, the result of a major geological event when two land masses collided and, in so doing, squeezed up from the bed of the Iapetus Ocean into what became the Borders. Hence, as local historian Alistair Moffat comments, 'the Borders came neither out of England or out of Scotland but appeared first as they have always remained, independent of either' (Moffat 2002, p. 25). It is the Unconformity at Siccar Point in Berwickshire (Figure 5) that Hutton found a year later, which has become the more celebrated site and which confirmed Hutton's theory that the Earth was much older than had been previously understood. This was a seismic shift that ushered in the concept of 'deep time' and an understanding of worldmaking as a process of deposition, uplift and erosion.

13 I was introduced to this way of walking by choreographer Russell Dumas when studying with him on occasions in France between 1999 and 2001. 


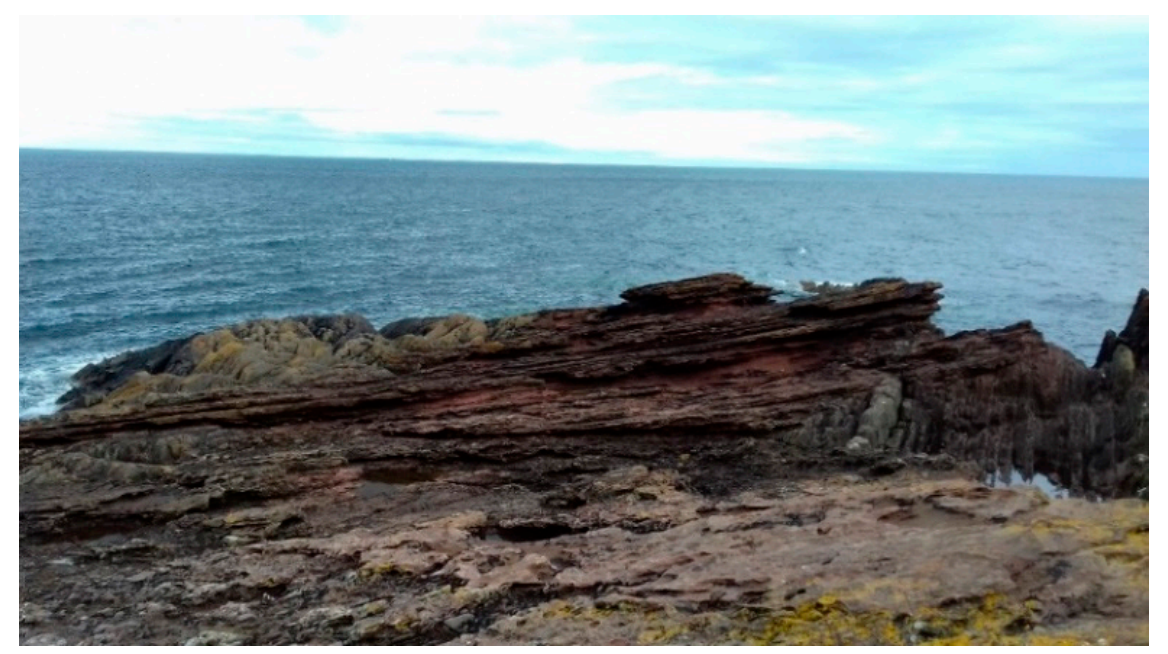

Figure 5. Unconformity at Siccar Point, Berwickshire. Image, author's own.

The Unconformity makes this event visible through the 'small pleats' (Hawkes 1951, p. 48) or vertical folds that do not correspond to our usual expectation for geological strata to be built up and laid down in horizontal layers (Figure 6). It is 'unconforming' in that time is not present as a sequential and continuous narrative. The storyline is broken. The vertical, folded rocks that were once mountains have eroded and, in the process, erased 65 million years between themselves and the more recent horizontal sandstone strata. The geological story is revealed in its incompleteness-in the 'gap'. Time is seemingly not set in stone. The Inchbonny site is most often represented through the 1787 engraving by the Scottish merchant, artist and geologist John Clerk of Eldin. The site today is overgrown and almost invisible, the horse and carriages replaced by the cars, trucks and bikes travelling along the A68.

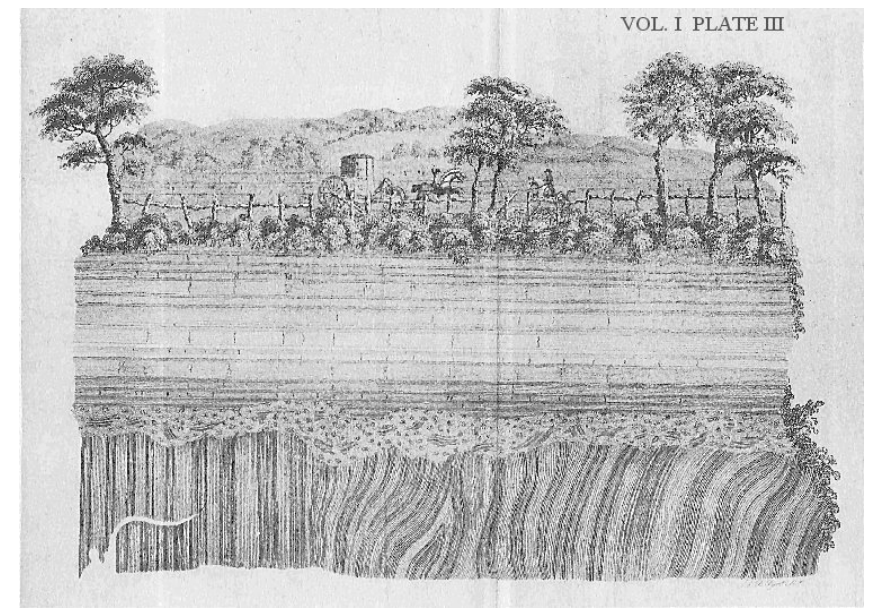

Figure 6. Engraving of the Unconformity at Inchbonny, near Jedburgh, by Scottish merchant, artist and geologist John Clerk of Eldin. In 'Theory of the Earth' by James Hutton. Image courtesy of (C) British Library Board, General Reference Collection 1651/958. 32.i.8-9.

\subsection{Entr'actes: Alternative Arrangements}

'We are not to look for nature in a quiescent state; matter itself must be in motion, and the scenes of life a continued or repeated series of agitations and events' (Hutton 1788). Hutton here identifies movement-'motion' — as a worldmaking process. This quote provided the starting point for a collaborative project with visual artist Felicity Bristow. The first iteration, 'Entr'actes: Alternative Arrangements', was a ten-hour durational studio performance at The Bakery, Jedburgh, 
in November 2017. ${ }^{14}$ Working with real-time composition processes alongside each other, we could choose to pursue independent strands of interest and be affected by what the other was doing. To sustain the activity over the duration and to build a reflective element into the event, we scored the day so that two hours of making would be followed by a reflective conversation-our entr'acte. Traditionally the entr'acte was an interlude between two acts of an opera or play, usually taking the form of a dance or music piece. Its function was to break up a longer performance by providing a 'something else', usually treated as a bit of light relief. The form of the entr'acte allows for something else to happen, a different activity to take place. It connects one part to another, not through more of the same but by doing something else. A 'small act', a fragment, as a connecting compositional element that adds to a whole by being a counterpoint, another perspective, an in-between research. Entr'actes could be a motional proposition for thinking through place. Other entr'actes emerged in the comings and goings of the public throughout the day. We explored themes that the Unconformity offered up-erosion, extraction, accumulation, uplift and folding. 'And I was thinking to work with edge', Felicity said at one point, which she did through her work with paper and I through working with the body and the architecture. 'I started to have a sense of ... how 'to crumple' is different from 'to fold' ... it's a different kind of going in on itself'. ${ }^{15}$ As edges are brought together in folding the contours and size of the original form, change becoming literally, enfolded or gathered into itself. As a compositional proposition, we could say that place is enfolded into a site- that site gathers the wider context of place or world into itself. Composing from this perspective requires that what is 'beyond' is incorporated. If we understand placemaking as a compositional process, this then draws us away from a view of place as bounded, and instead, placemaking becomes a process of acknowledging influences, connections and responsibilities.

\section{Riverways: Confluences}

An interpretation board in the car park beside Jedburgh Abbey explains that Jedburgh-formerly Jedworo-Jedworth-means '[a]n open space at the bend of a river'. Another source suggests a derivation from the proto-Indo-European *wei $\left(h_{1}\right)-d$-, "a bend, something curved or twisted" (James 2019, pp. 298-90). This is the contour of a geopoetic language. The bend is a meander; it is how a river shapes and organises itself as it goes along on a sidewinding course through the territories. A stravaiging riverway. The Jed Water makes its way to join the Teviot near Jedfoot Bridge and continues to connect with the Tweed at Kelso. Confluences and river meetings make good places to reflect on collaboration. As part of World Listening Day 2013, the lead artists of 'Working the Tweed', Kate Foster, Jules Horne, James Wyness and myself, invited people to go to their closest river confluence to listen and to record the experience in some way. ${ }^{16}$ Jules Horne went to the confluence of Teviot and Tweed, where 'Kelso is obliterated by a constant rush of white noise. The pool itself is quiet, the water slow-moving. The white noise comes from a cauld [weir], used by the salmon and trout to travel upstream ... . It's like a sound bed that cushions and blunts everything else' ${ }^{17}$

\subsection{River Seams: A Fisherman's Perspective}

This is the Tweed just below Kelso Bridge, and it's not very typical of the whole river because the arches of the bridge has three streams. You can see we've got the fast stream in front of us here, then there's a stream that comes through the middle arch and it meets quite quickly with the stream that

14 This took place on 19 November 2017 as part of Mapping the Borders, an event curated by Inge Panneels as part of the Being Human Festival 2017: https://beinghumanfestival.org/events/series/mapping-the-borders/.

15 From the transcript of a reflective conversation with Felicity Bristow 19 November 2017.

16 Here are a selection of river listening reflections: https://workingthetweed.co.uk/2013/07/29/cogsmill-burn-slitrig-teviottweed-world-listening-day-reflection and https://workingthetweed.co.uk/2013/07/21/listening-upriver-downriver/ and https://workingthetweed.co.uk/2013/06/28/the-riparian-listener-or-knowing-the-river/.

17 From Jules Horne's World Listening Day blog: https:/workingthetweed.co.uk/2013/07/22/teviot-meets-tweed/. 
comes out the third arch. But I'll take the stream in front of us here as a typical stream that a river fisherman would be faced with. You can see we've got the quiet water and the shallower water close to the bank. Out there in the middle it's very fast flowing and that duck (laugh), that just happens to be sitting there, you'll notice that's an area where the water, that's what we call the seam; it's the merge between the very fast water and the dead water. And the trout love that area because they've got the sanctuary of the fast, deeper water ... they don't want to be sitting in the dead water because the flies that are drifting towards them obviously in dead water it's not drifting towards them, but in that seam, it's almost like a magnet for everything drifting down the river... That seam is the attraction, it's almost like a motorway and we look for fish feeding in that seam ... It's a wider seam the further down towards the pool you go and then as you get up into this very fast water its quite a narrow seam and probably you're thinking, if I look up there well I can't actually see much difference but over the years with experience a fisherman can see maybe a two feet wide section there, right in front of us here, there's probably a four or five feet section that a trout would preferably lie in and then further down there's probably a ten or a twelve foot section. ${ }^{18}$

Here, Ronnie Glass takes us right into the hydrology and speaks a river tongue. The word 'seam' resonates particularly here in the Scottish Borders, where the textile industry has shaped the communities and language of the territory. A seam joins the edges of different pieces of cloth; it is a junction, a meeting and a merging place. As in the earlier reference to how deer managers might practice peripheral vision before entering into deer territory, this river passage is another example of how traditional practices or skills of connection with the more than-human world can still be found in these predominantly rural activities and in the vocabulary associated with them.

\subsection{Not-So-New Cartographies}

In the Northwest Pacific Coast, it was traditional for each First Nations tribes to divide up and manage their civilizations by watershed. (Durning 2004 in Hamilton 2008, p. 12)

Having been taken into the depths of a specific place in the river with a fisherman's experienced eye, we now zoom out to look at the river system as a whole. This River Ways drawing, created by Kate Foster (Figure 7), was developed as a conversation piece for the 'Knowing Your River' events as part of the arts-science collaboration 'Working the Tweed'. People were drawn to the image and saw in it not only a representation of the Tweed Catchment but also the patterning of leaves and lungs. It became a mapping or a reading across species, which brought together rivers, trees and humans. Seen through this catchment perspective, the story of an unconnected region divided through 'rivalis' is replaced by a densely connected, more-than-human network from source to sea. It becomes a way to begin to imagine collaboration and co-creation in the region. Choreographically speaking, it could be a score for joining in. It is a partial representation, as the drawing does not tell us about the 'thickness' of individual places. It flattens out the individuation of each tributary and confluence, but we can still see that tributaries have their own starting points—-the sources from which they emerge-and their individual flow ways. Wherever they meet, each tributary contributes to the accumulating water that eventually flows out over the geopolitical borders and into the North Sea. River Ways is a bioregional mapping, which echoes the Valley Section diagram (Figure 8) created by Patrick Geddes. This regional survey tool, similar to the actual view from the top of his Outlook Tower in Edinburgh out towards the Pentland hills, makes the interrelationship between the urban and rural, the local and the global, apparent. It was Geddes, after all, who coined the phrase 'think global, act local'.

18 Transcribed from an interview by Jules Horne for Working the Tweed, 2013. 


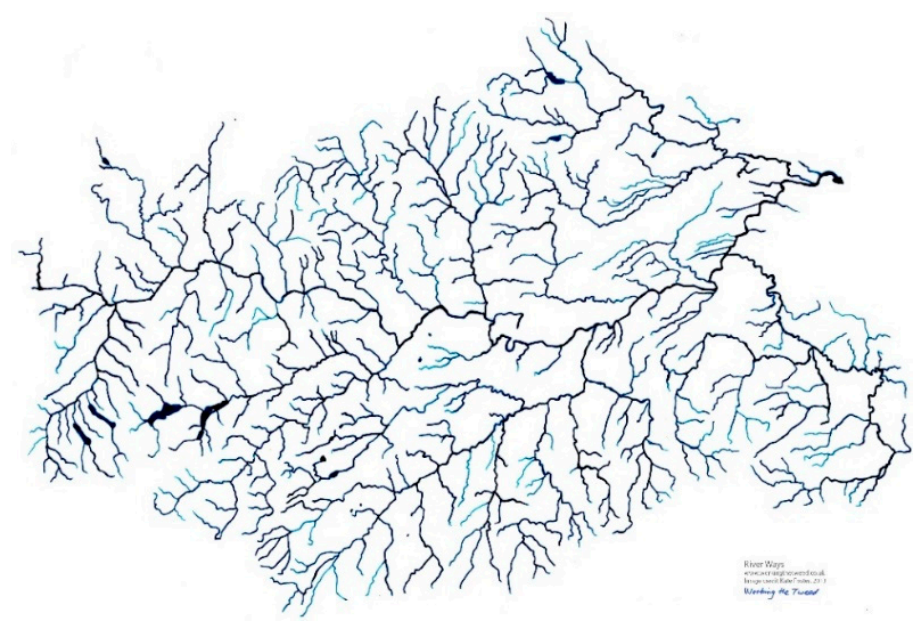

Figure 7. River Ways, from 'Working the Tweed'. Image permission of Kate Foster.

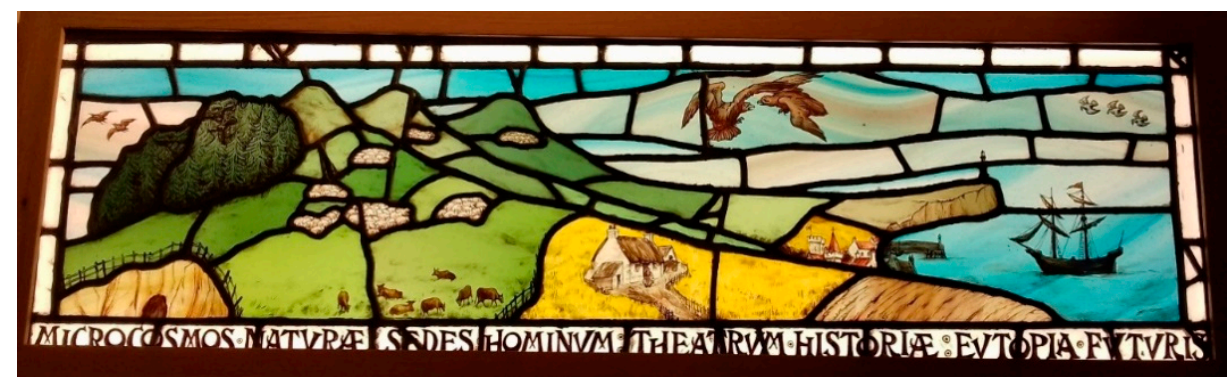

Figure 8. Valley Section, stained glass panel in Patrick Geddes Centre, Riddles Court, Edinburgh. Image, author's own.

Rural areas would have been more highly populated in Geddes' time than now, and the relationship of the country to the city has become increasingly 'fragmented, disconnected and unappreciated' (Hamilton 2008, p. 6). In the footsteps of Geddes, 'meshworker' Marilyn Hamilton writes that an 'intelligent Integral City ... would nurture its ecoregion with integrity and awareness that their lives were intimately connected ... It is fast becoming a mark of city responsibility as well as city resilience' (Hamilton 2008, p. 7). Val Plumwood's 'critical reworking or reframing of bioregionalism' (Plumwood 2008, p. 140) reconfigures place in a more ethical and environmentally responsible way, recognising that nowhere is 'singular and self-sufficient' (Plumwood 2008, p. 139). She challenges us to acknowledge the role of other places that support our ways of life. Place is now more than one, and responsibility in a global market goes beyond the local watershed and extends to places on the other side of the globe. Here, I fold this perspective into the Tweed Catchment, where the relationships are source to sea and beyond and tributary to main river stem. This is a different view of the Scottish Borders, one that underlines an integrated and connected region rather than the rivalry of individual towns. 'At all scales, life on Earth is made up of interdependencies, interactions, and communication; this is so all the way "up" to the biosphere and "down" to the single cell. The emphasis is on the openness of systems' (Rose 2017, p. 499). Scaling down to a cellular level takes us right back into the domain of somatic practice, in particular the work of Bonnie Bainbridge Cohen and Body-Mind Centering ${ }^{\circledR}$ (Cohen 1995).

\section{Under_Standing Place: Grounding Practice}

A geopoetic 'open world' perspective looks for distinctiveness 'not in piety of place ... but with knowledge (informed, sentient, intelligent) of place. Thoroughly known, every place is open' (White 2003a, p. 20). 'Going into the background, re-examining the territories' is the geopoetic way into the open world (White 2006, p. 6). In a very modest way, the 'under_standing' process I describe 
below is a way of re-grounding, of going back into the territories. Under_standing is a term drawn from the teaching of Dominique Dupuy. Here, it conveys how knowledge is created through being in a dynamic relationship with materials and space.

\section{Under_Standing Practice}

Find a good place to stand with your (ideally bare) feet a fist width apart. Close your eyes, if it is helpful, to begin with. Open the soles of the feet into the floor and allow space behind the knees so that they are not locked. Drop your weight down into the floor and activate your contact through the feet by slightly pushing into the ground. Imagine that it pushes back so that your standing is energetic, supported and a process of dynamic exchange. Stand, literally, from underneath. In this way, knowing is communicated through the soles of the feet into the central nervous system. Your standing will never be still. There will always be small adjustments in the spine and around the feet. Maintaining the connection into and with the ground, take your attention to the crown of your head. Open up and inhabit the space between the ground and the sky. Continuing to work with this under_standing, go for a walk.

White notes that 'The word tao, 'way', is written in Chinese with two root characters, the one representing 'feet', the other 'head'. Taoism, then, could mean something like 'how to move with your head' or 'how to make headway'. (White 2004, p. 105). Where White stays in the 'head space', I am instinctively drawn towards an interpretation of the Chinese characters that is expressed in the under_standing practice above, where understanding is the integration of knowing that is embodied and created through the act of being in contact with. Or, as White writes, 'a world emerges from the contact between the human being and the cosmos, represented by the Earth' (White 2003a, p. 3). Connection to the ground also allows us, in our moving through, to be shaped and bodied by more-than-human others. In moving between, around, under and over, thought is composed and bodied. This is space recognised as a vibrant dynamic material-an energetic and organising material. Choreographer Michael Kliën remarks:

I have always had a sense that a thought is a physical act and I have always been discontent with people in the dance world who want to get over the Cartesian split by just talking about the body ... You propagate the same idea, just from the other side.... Conversational patterns are thoughts, they are not just up there (points to his head). Thought can be everywhere. Thoughts are between us. (Klien and Valk 2007, p. 3)

In-between-ness opens up a mutable, fluid and shareable spatial terrain that invites dialogue, correspondences and exchange and counters the duality and other side-ness of edges and borders where crossings might be more controlled. In-between-ness is also about transitions, the passage of movement through that is afforded much attention in contemporary dance, as the specificity of the transition shapes the movement yet to come.

\section{Conclusions}

The woodland way, stone way and riverway investigations each generated practices or scores for dwelling inspired by more-than-human interactions and with some of the people who work in these environments. Woodland ways expanded our horizons and, in keeping the edges in view, encouraged a sense of wide openness and a way of moving through that was more attuned, considered and less predatory. Moving beyond the skin and into materials offered a process for co-creating 'with' and influenced how we worked with space/place. Stone ways and the Unconformity site took us beyond placemaking to the worldmaking perspective of geology and the ongoing processes of change that unsettle any notion of fixity of place. The complexity of the Unconformity site, where the edges come together as folds, offers an alternative configuration of a 'border' from the usual dividing line on the map, which reinforces the oppositional and confrontational duality of being on this side or that. In the spirit of unconforming, it ruptures rehearsed narratives, rearranges positionings and points of view by bringing different parts into contact with each other and acknowledges a greater complexity and 
density of relationship. Through the under_standing practice and stone ways explorations, a more dynamic relationship to the ground was experienced through contact with the density and surface of stone. Contact-contour was in action here. In reworking edge to become fold, the 'border-line' was re-patterned and became (en)folded into site. Riverways provides some different vocabulary to think about place. There is 'meander' as a way to shape and organise movement through and on the way to; 'confluence' as a place of collaboration, meeting and exchange; and 'seam', which allows for merge. Scaled up to a catchment model, the riverways create scores for collaboration that encourage diversity and participation. As an integrating system of water, what happens in one place will affect somewhere else in the catchment. As Professor Chris Soulsby, Chair in Hydrology, University of Aberdeen, explained, '[t]hat's why protection of water is so important; for example, agricultural or industrial pollutants input into the catchment today, may still be draining into the river in hundreds of years' time!'19

In this paper, I have been moving within, into and through the Scottish Borders to reflect on edges, peripheries and boundaries to look for alternative compositions of place, narratives other than those based on rivalry and a less singular vision. If we 'unfold' this now to the wider Scottish context and towards the planning field in particular, as placemaking is one of its concerns, then these scores and practices ask for the revitalising of a framework and a vision that is composed not through the single lens of, for example, economic growth, but with an open world perspective that actively allows itself to be shaped by the more-than-human and that brings different fields of knowledge into contact with one another. If we think of site as an enfolded place, then by extension, place becomes an enfolded world - a construct that encourages more ethical and ecological relationships to other places. The voices and ways of more-than-human others are given agency and presence, and the 'no man's land' often associated with border territories can perhaps become reinterpreted, literally, to make space for placemaking that is neither human-led nor focused. 'On careful reflection, we can all think of ways to negotiate, redefine or even reclassify the boundaries, and when we do so, we change the systems they serve and our relationship to them'. (Hamilton 2008, p. 30). Working from the context of somatic movement, practice has brought the intelligence, competencies and complexities of the different perceptual systems and layers of the body-mind into contact with place. The movement practices and activities described are a gathering of embodied knowledges that have been passed on and disseminated from body to body. They are not in themselves original, but they have lineages, and they bring to the enquiry different vocabularies, motion as an active shaping force and different ways of composing 'self'. In seeking different configurations of place and to unsettle narratives, we must be prepared to shapeshift ourselves, to unlearn habitual patterns of moving and thereby thinking, in order to find something else. I have shown through different examples how somatic practices can be used as a tuning experience to heighten perceptual awareness to suggest other ways of being in relation with what is beyond the skin, how body-mind is distributed and not held in one place and how we are composed through brushing up against and being in the world. These competencies prepare the potential for us to be present with the world in more playful, respectful and sensitive ways. Alongside more traditional practices of connection, transmission is from body to body rather than through academic texts and, as such, is situated at the edges of education and scholarly debate. The question is how this field of research might best find a wider expression beyond the world of movement practice. The answer is, perhaps, firstly, by bringing itself into relationship with and brushing up against other fields of knowledge and activity and by using its capacities to make small transformations.

Funding: This research received no external funding.

Acknowledgments: I would like to acknowledge the advice of Julie Crawshaw in the writing of this paper.

Conflicts of Interest: The author declares no conflicts of interest.

19 From a blog post 'Old Water/New Water' https://workingthetweed.co.uk/2015/03/10/young-water-old-water/. 


\section{References}

Bennett, Jane. 2010. Vibrant Matter: A Political Ecology of Things. Durham: Duke University Press.

Cohen, Bonnie Bainbridge. 1995. Sensing, feeling, and action: The experiential anatomy of body-mind centering. In Bone, Breath and Gesture. Practices of Embodiment. Edited by D. Hanlon Johnson. Berkeley: North Atlantic Books, pp. 175-91.

Durning, Alan. 2004. Cascadia Scorecard. Seattle: North West Environment Watch.

Forsythe, William. n.d. Choreographic Objects. Available online: https://www.williamforsythe.com/essay.html (accessed on 5 August 2019).

Gibbs, Leah. 2014. Arts-science collaboration, embodied research methods, and the politics of belonging: 'SiteWorks' and the Shoalhaven River, Australia. Cultural Geographies 21: 207-27. [CrossRef]

Hamilton, Marilyn. 2008. Integral City. Evolutionary Intelligences for the Human Hive. Gabriola Island: New Society Publishers.

Hawkes, Jacquetta. 1951. A Land, 2012 ed. London: Collins.

Hutton, James. 1788. Theory of the Earth. Canton: NuVision Publications, LLC.

Irvine, Rosanna. 2016. Contemporaneity and micropolitics in the processes of Perception Frames. Choreographic Practices 7: 119-37. [CrossRef]

James, Alan G. 2019. The Brittonic Language in the Old North. A Guide to the Place-Name Evidence, vol. 2. Available online: https://spns.org.uk/wp-content/uploads/2019/03/Alan_James_Brittonic_Language_in_the_ Old_North_BLITON_Volume_II_Dictionary_2019_Edition.pdf (accessed on 5 August 2019).

Juhan, Deane. 1995. Bone, Breath, Gesture. Practices of Embodiment. Edited by D. Hanlon Johnson. Berkeley: North Atlantic Books, pp. 353-78.

Kimmerer, Robin Wall. 2003. Gathering Moss: A Natural and Cultural History of Mosses. Corvallis: Oregon State University Press.

Klien, Michael, and Steve Valk. 2007. What Do You Choreograph at the End of the World? Zodiak: Unden Taussin Taehen. Stephen, Walter. 2015. Patrick Geddes: Environment and Culture. In Think Global, Act Local. The Life and Legacy of Patrick Geddes. Edited by Walter Stephen. Edinburgh: Luath Press Limited, pp. 70-84.

Manning, Erin. 2013. Always More Than One: Individuation's Dance. Durham and London: Duke University Press. Massey, Doreen, Human Geography Research Group, Sophie Bond, and David Featherstone. 2009. The Possibilities of a Politics of Place Beyond Place? A Conversation with Doreen Massey. Scottish Geographical Journal 125: 401-20. [CrossRef]

Moffat, Alistair. 2002. The Borders. A History of the Borders from the Earliest Times, 2007 ed. Edinburgh: Birlinn.

Nelson, Lisa. 2004. Before Your Eyes. Seeds of a Dance Practice. Contact Quarterly 29: 20-26.

Openshaw, Noble. 2014. A Cultural Strategy for the Scottish Borders. Available online: https://www.scotborders. gov.uk/downloads/file/2896/cultural_strategy (accessed on 4 July 2019).

Overlie, Mary. 2016. Standing in Space. The Six Viewpoints Theory and Practice. Billings: Fallon Press.

Plumwood, Val. 2008. Shadow places and the politics of dwelling. Australian Humanities Review 44: 139-150.

Rose, Deborah Bird. 2017. Connectivity Thinking, Animism, and the Pursuit of Liveliness. Educational Theory 67: 491-508. [CrossRef]

Schiller, Gretchen, and Sarah Rubidge. 2014. Choreographic Dwellings: Practising Place. London: Palgrave Macmillan UK. Straus, Erwin. 1966. Phenomenological Psychology. New York: Basic Books.

White, Kenneth. 1984. Écosse. Paris: Éditions Arthaud.

White, Kenneth. 2003a. Geopoetics. Place Culture World. Glasgow: Alba Editions.

White, Kenneth. 2003b. Open World. The Collected Poems 1960-2000. Edinburgh: Polygon Books.

White, Kenneth. 2004. The Wanderer and His Charts. Essays on Cultural Renewal. Edinburgh: Polygon.

White, Kenneth. 2006. Along the High Lines. Figuring Out the Way to a World Culture. Paper presented at the Edinburgh International Book Festival, Edinburgh, UK, August 27.

Worth, Libby. 2004. Anna Halprin. London: Routledge.

(C) 2019 by the author. Licensee MDPI, Basel, Switzerland. This article is an open access article distributed under the terms and conditions of the Creative Commons Attribution (CC BY) license (http://creativecommons.org/licenses/by/4.0/). 